\title{
Mobile Banking: Evidence from Portugal
}

\author{
A. Fragata \\ Viseu Polytechnic Institute, \\ CI\&DEI- Centro de Estudos em Educação e Inovação \\ E. Moustakas \\ Middlesex University Dubai \\ H. Teixeira \\ Viseu Polytechnic Institute, \\ CI\&DEI- Centro de Estudos em Educação e Inovação
}

\section{Cruz-Lopes}

Viseu Polytechnic Institute, CERNAS- Center for Studies in Natural Resources Environment and Society

\begin{abstract}
The paper intends to empirically examine the motivators that influence consumers' intentions to use Mobile Banking in Portugal. The data was analyzed by employing exploratory as well as confirmatory analysis and a Structural Equation Model was extracted from 172 Portuguese respondents. The findings indicate that Portuguese consumers still prefer Online Banking rather than Mobile Banking. The Structural Equation model indicates that 'Perceived ease of use' and 'Perceived Usefullness' were the primary determinants of the Intention to use Mobile Banking. it is also found that 'Lack of information' and 'Use Barriers' are antecedents of Perceived Risk, which influence negatively the Intention to use Mobile Banking.
\end{abstract}

Keywords: Mobile Banking in Portugal, Perceived Risk, Perceived Usefulness, Perceived Ease of Use, Use Barriers, Lack of Information

\section{INTRODUCTION}

Mobile banking is an innovative service provided by a bank or other financial institution and is primarily powered by communication technology which is one of the world's fastest growing sectors. Rapid innovation and increasing competition has revolutionised the services landscape, resulting in providers shifting from traditional face-to-face encounters, to ones that are technology-based, in order to increase efficiency and decrease operating costs. Over the past decade, the emergence of mobile self-service technologies has provided banking organisations greater opportunities to capture new markets. Like in any emerging technology, there are barriers for the adoption of mobile banking services. The current research explores the determinants of intention to adopt Mobile Banking services in Portugal.

\section{LITERATURE REVIEW}

This paper aims to investigate the general usage of mobile services as well as the influence of demographic characteristics on mobile banking usage. The paradigm shift, from traditional branch banking to electronic banking, the newly emerged channels and the rapidly increasing penetration rates of mobile phones are some of the motivators of this study. The approach employed is practical and provides insights drawn from the quantitative empirical survey. The newly emerged mobile banking services represent an innovation where both an intangible service and an innovative medium of service delivery employing high technology are present. 
An impediment seems to be the functionality of a mobile phone as delivery medium for banking services. There are cases where mobile phones are not designed for this type of services: For instance, keyboard is relatively small, which makes it more prone for correcting errors in keeping the figures [1]-[2]. Therefore, we propose the following hypothesis:

\section{H1: Barriers in using mobile phones will have a negative impact towards the intention to use Mobile Banking.}

The second additional construct is 'Perceived Risk', which is the consumer's belief regarding the likelihood of suffering a loss in pursuit of a goal [3]. Studies in M- commerce [4] and wireless finance [5] have shown that high perceived risk has a negative influence on technology adoption. Research suggests that highly personalized and context-based technology, such as Mobile Banking, carries an inherently higher perception of risk [6]. As Mobile Banking is information lean and mobile, it creates higher levels of uncertainty and risk perceptions [7]-[8]. The result of perceived risk on the adoption of mobile banking services appears to indicate that consumers are serious about the risk of conducting banking via a wireless channel, measured in terms of overall security and trustworthiness of the services offered. Based on the findings, it is suggested that service providers should be aware of the challenges of their customers using mobile services. This kind of data has its value when designing new services and products or implementing market communications [9]. Therefore, we propose the following hypothesis:

\section{H2: The perceived risk will have a negative impact towards the intention to use Mobile Banking.}

Results indicate that consumers get disheartened by the complicated functions while accessing the mobile banking services which lead them to the dissatisfaction level as no proper guidance is to be provided to them. Studies have shown that the more introduction of an e-payment or online banking service is not sufficient to attract users [7]. Banking organisations should also highlight the relative advantages of $\mathrm{m}$-services and emphasise these aspects in promotional materials [3].

Therefore, we propose the following hypothesis:

\section{H3: Lack of Information will have a negative impact towards the intention to use Mobile Banking.}

'Perceived usefulness' is defined as the degree to which a person believes that a given system or technology can improve his daily, personal, or professional activity [10]. This construct is also related to the concept of relative advantage since the user will only change its behavior if the new technology is considered more advantageous than its predecessor. There is inevitably a comparison between substitute technologies, cost and performance [1]. In the context of mobile banking, there are authors who point out that in order to evaluate the perceived usefulness, the consumer must interact with the service in its different versions, such as through computer and mobile phone. It is through experimentation that the consumer can compare the services and order their preferences [11]. Several studies, have verified that the perceived usefulness is a significant determinant in the intention to use new technologies. Hence some studies such as those in the studies conducted by [12] and [13] have introduced predictors of perceived usefulness. As author's in [12] point out, a better understanding of the determinants of perceived usefulness will allow us to design organizational interventions that will increase the number of users of new systems. Therefore, we propose the following hypothesis: 


\section{H4: The perceived usefulness will have a positive impact towards the intention to use Mobile Banking.}

Perceived ease of use is related to the autonomy or degree of effort required to use a technology [10]. If the client is more literate in new technologies, his ease of use will be greater and so his level of trust [13]. In addition, it becomes a challenge for companies to define userfriendliness parameters for their customers. There are cases of companies that have not adapted the content of their web pages to mobile devices and in this way their usability is more complex. Even though more and more people have smartphones with larger dimensions than the palm of the hand, many still have mobile phones with small screen and keyboard, and that discourages the use of mobile services [1]. Customers prefer simple textual content. Thus, in the case of blind people, they can access information through a voice reader [14]. The first studies on mobile banking demonstrated that because the screens were small it made some operations difficult and time consuming, since it was not possible to see all the information. So, there was disinterest in its use [1]. For this reason, mobile banking systems should be easy to use and learn, in accordance with the device that integrates them [15]. Therefore, we propose the following hypothesis:

H5: The perceived ease of use will have a positive impact towards the intention to use Mobile Banking.

Another additional construct is 'interaction', which is the desire to retain personal contact with service personnel during a service encounter [16]. The need for Personal Interaction is one of the constructs highlighted in the studies on self-service technologies, since it can lead to resistance of potential users.

According to the authors in [17] the need for interaction is defined as the desire to establish personal contact during a service. This is because over time several interactions have developed between the client and the service provider, leading to an interpersonal relationship. These interpersonal relationships lead to greater closeness between individuals, which Self-service Technologies (SST) eventually eliminated. For this reason, the use of SST, where mobile banking is included, may be less appealing.

For many clients, interpersonal relationships and the need for interaction are valued and essential. In previous studies it is demonstrated that customers are more likely to become loyal if they develop a personal relationship with a contact employee, in a context of the traditional banking. The authors in [18] also concluded that the relationships generated between the decision maker of a company and the manager of a bank is an important antecedent of the perception of the E-Banking Service Quality and an important driver of E- banking loyalty.

In addition, authors report that the use of SST to some clients generates anxiety and stress [19]. Therefore, the need for personal interaction may lead to less use of m-banking [20]. However, other studies prove that consumers using mobile banking not only for convenience, but also to avoid contact with employees and clients [17].

Banking services have traditionally been "high touch" and "low tech" [21], customers who develop personal relationships with their banking providers may be less likely to use $\mathrm{m}$ banking. The author's in [17] developed the Model of Attitude and Intention to Use the SST, which complements the Technology Acceptance Model (TAM), in which they introduced: the need for personal interaction and risk. Therefore, we propose the following hypothesis:

H6: The interpersonal relationships generated between the client and the bank employee will have a negative impact towards the intentions to use Mobile Banking. 


\section{METHODOLOGY}

This study is based on both primary and secondary data sources. Primary data was collected through interviews with Online Banking and Mobile Banking users as well as non-users. We also randomly sent e-mails to to Facebook users within a short period of 10 days and through 172 valid responses were obtained. We released a brief explanation about the concept and purpose of the study and attached the Google form questionnaire hyperlink. We then used SPSS 24 for exploratory and confirmatory analysis and AMOS 24 for Structural Equation Modelling.

\section{FINDINGS}

Past and recent studies claim that the wide use of geographic, demographic, socio-economic and psychographic variables have not always been accepted as good predictors in examining buying behavior in financial services. Instead the benefits that customers seek for in banking services and/or the product attributes should be identified. Table I presents the demographic characteristics of the sample and in Figure I outlines the most used Portuguese banks for the respondents in our sample.

Table I- Demographic characteristics of the sample

\begin{tabular}{|c|c|c|c|}
\hline & & Frequency & Percent \\
\hline \multirow[t]{3}{*}{ Age } & $19-30$ & 38 & 22,1 \\
\hline & $31-40$ & 69 & 40,1 \\
\hline & $41-65$ & 65 & 37,8 \\
\hline \multirow[t]{4}{*}{ Education } & Phd & 29 & 16,9 \\
\hline & Secondary School & 19 & 11 \\
\hline & Degree & 102 & 59,3 \\
\hline & Master & 22 & 12,8 \\
\hline \multirow[t]{5}{*}{$\begin{array}{c}\text { Month } \\
\text { Income } €\end{array}$} & $>2000$ & 33 & 19,2 \\
\hline & $1001-1500$ & 49 & 28,5 \\
\hline & $1501-2000$ & 26 & 15,1 \\
\hline & 501-1000 & 42 & 24,4 \\
\hline & $<500$ & 22 & 12,8 \\
\hline
\end{tabular}

Figure I- Prefered bank

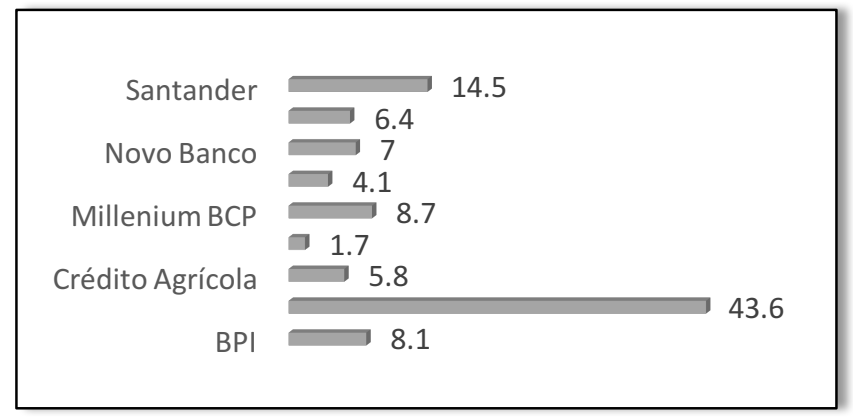

Figure II presents the results from our sample where only 53,5 \% are using Mobile Banking while $86 \%$ are using Online Banking technologies. Nevertheless, the findings indicate a penetration in the target market and therefore, the potential of this market should not be underestimated. Equally, there is some good potential for developing Portuguese mobile banking. 
Figure II- Use of Online and Mobile Banking

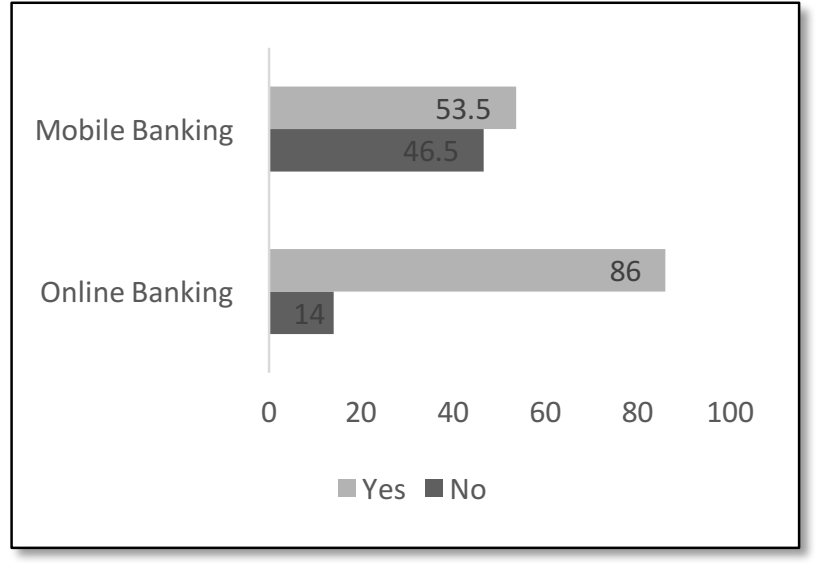

Figure III- Preferred channel for banking operations

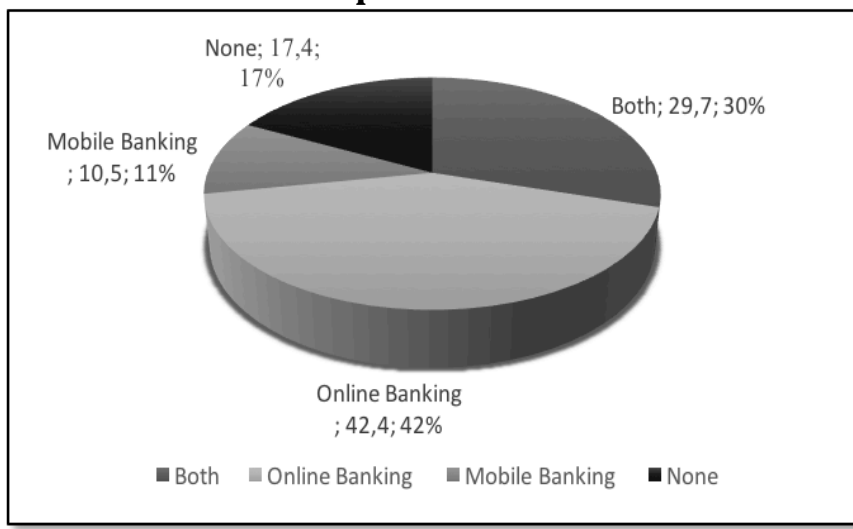

Figure IV- Structural Equation Model

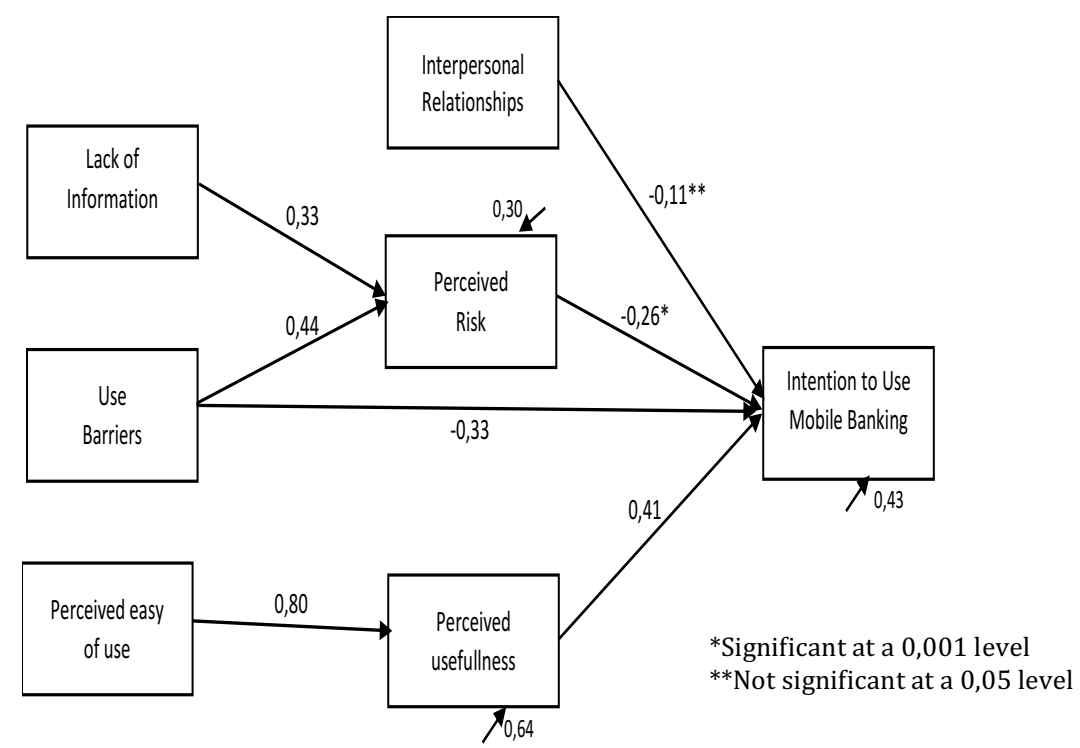

In Figure III, the results indicate that the $42,4 \%$ of the Portuguese bank clients prefer to use Online Banking, followed by a preference for both Online and Mobile Banking (29,7\%). The literature suggests that consumers prefer a mix of the two channels rather than a single delivery channel [22] and that it would be important for service providers to understand and improve each channel within the overall service offering rather than concentrating efforts on improving one delivery channel in isolation [23]. Our results also suggest that for 52,3\% of the respondents the main advantage in using Mobile Banking is the easy access in any place any time, followed by time saving (14,5\%).

Figure IV presents the final structural equation model and in Table II the exploratory and confirmatory analysis. The global fit for the present structural equation model was acceptable: $X^{2}=382,5, d f=163 ; \mathrm{CFI}=0,919 ; \mathrm{TLI}=0,906 ; \mathrm{GFI}=0,812$; $\mathrm{RMSEA}=0,089$ and $\mathrm{AGFI}=0,758$. Use Barriers in using Use barriers mobile phones have direct negative effect $(-0,33)$ on Intention to use Mobile Banking.

There is also evidence found for accepting the proposed Hypothesis 2, that the perceived risk will have a negative impact $(-0,26)$ towards the Intention to use Mobile Banking. 
Evidence was also found in order to support the Hypothesis 3 since Lack of Information is an indirect negative effect $(-0,083)$ on Intention, trough Perceived Risk. Banks should pay more attention on the fact that Lack of information and Use Barriers will increase perceived risk in the perception of adopting mobile banking services. Portuguese bbanking organisations should highlight the relative advantages of mobile services and emphasise these aspects in promotional materials.

The research results also support hypothesis 4 that the Perceived Usefulness has a positive impact $(0,41)$ on Intention to Use Mobile Banking. For the proposed Hypothesis 5 , it was found an indirect positive effect on intention to Use Mobile Banking trough Perceived Usefulness, with a total indirect impact of 0,332, consistent with the study conducted by [24]. We conclude that banks should pay more attention to this fact that Perceived Ease of Use and Usefulness have the strongest impact in adoption of mobile banking technologies. No evidence was found in the sample for accepting Hypothesis 6 that the interpersonal relationships generated between the client and the bank employee will have a negative impact towards the Intention to use Mobile Banking. In the research sample the interaction between the client and the personal relationship with the bank employee seems to be irrelevant in the process of adoption of Mobile Banking.

Table II- Exploratory and confirmatory analysis

\begin{tabular}{|c|c|c|c|c|c|}
\hline $\begin{array}{l}\stackrel{n}{0} \\
\stackrel{0}{2} \\
\stackrel{ \pm}{ \pm} \\
0 \\
0\end{array}$ & Name & $\begin{array}{l}\text { Factor } \\
\text { scores }\end{array}$ & $\begin{array}{c}\text { Bartlett's } \\
\text { Test }\end{array}$ & $\begin{array}{c}\text { Total } \\
\text { variance } \\
\text { extracted } \\
\%\end{array}$ & $\begin{array}{c}\text { Cronbach } \\
\text { Alpha }\end{array}$ \\
\hline 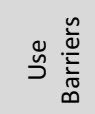 & $\begin{array}{l}\text { BU1 } \\
\text { BU2 } \\
\text { BU3 }\end{array}$ & $\begin{array}{l}0,945 \\
0,894 \\
0,943\end{array}$ & 395,058 & $86 \%$ & 0,918 \\
\hline 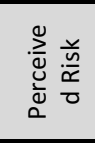 & $\begin{array}{l}\text { RP1 } \\
\text { RP2 } \\
\text { RP3 } \\
\text { RP4 } \\
\end{array}$ & $\begin{array}{l}0,881 \\
0,739 \\
0,900 \\
0,846 \\
\end{array}$ & 376,120 & $71,36 \%$ & 0,858 \\
\hline 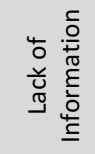 & $\begin{array}{l}\mathrm{Fl} 1 \\
\mathrm{FI} 2\end{array}$ & $\begin{array}{l}0,960 \\
0,960\end{array}$ & 210,134 & $92,147 \%$ & 0,915 \\
\hline 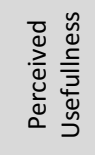 & $\begin{array}{l}\text { UP1 } \\
\text { UP2 } \\
\text { UP3 }\end{array}$ & $\begin{array}{l}0,900 \\
0,888 \\
0,886\end{array}$ & 252,4 & $79,479 \%$ & 0,869 \\
\hline 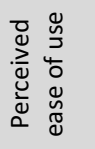 & $\begin{array}{l}\text { FUP1 } \\
\text { FUP2 } \\
\text { FUP3 }\end{array}$ & $\begin{array}{l}0,963 \\
0,959 \\
0,926\end{array}$ & 510,3 & $90,13 \%$ & 0,896 \\
\hline 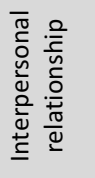 & $\begin{array}{l}\text { RI1 } \\
\text { RI2 }\end{array}$ & $\begin{array}{l}0,952 \\
0,952\end{array}$ & 181,804 & $90,555 \%$ & 0,896 \\
\hline 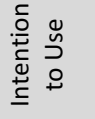 & $\begin{array}{l}\text { IU1 } \\
\text { IU2 } \\
\text { IU3 }\end{array}$ & $\begin{array}{l}0,923 \\
0,875 \\
0,913\end{array}$ & 297,220 & $81,74 \%$ & 0,888 \\
\hline
\end{tabular}




\section{CONCLUSIONS}

This qualitative study has identified the key factors influencing customer decisions to adopt Mobile Banking in the context of a multi-channel service offering. The findings served as the basis for the development of a model that attempts to structure the determinants on intention to use Mobile Banking services, since the findings suggest that a bigger percentage of Portuguese customers still prefer the Internet Banking channel, and that banks have a more potential market to develop on the mobile channel. Rather than concentrating efforts on improvements to each channel in isolation, it is important to understand and improve the contribution of each channel to customer satisfaction within the overall banking service offering.

Bank's should make more effort to communicate with their clients the advantages of using this new technology on their daily banking operations since Usefulness is found as an important determinant on intention to use mobile banking. It is also a challenge for banks to define userfriendliness parameters for their customers, adapting the content of their web pages to mobile devices so that their usability is less complex. Our findings also support the fact that perceived ease of use is an important antecedent of perceived usefulness and therefore affects the intention to use Mobile banking.

Lack of information and Use barriers are also important antecedents on the perception of risk, which has a negative impact on intention to use Mobile Banking.

It is crucial for banks to improve consumer education programs, with user guidance to reduce perceived risk and communicate the advantages of using this new mobile channel on their promotional materials.

The findings of this research give financial institutions in Portugal a foundational model that can be used to provide insights into marketing strategies that could be used to increase usage of Mobile Banking.

\section{References}

Laukkanen, T., and Cruz, P. (2009). Comparing consumer resistance to mobile banking in Finland and Portugal $e$ Business and Telecommunications (pp. 89-98): Springer.

Lee, E. J., Lee, J., and Eastwood, D. (2003). A two-step estimation of consumer adoption of technology-based service innovations. Journal of Consumer Affairs, 37(2), 256-282.

Pavlou, P.A. (2003), “Consumer acceptance of electronic commerce: integrating trust and risk with the technology acceptance model”, International Journal of Electronic Commerce, Vol. 7 No. 3, pp. 101-134.

Wu. J. and Wang, S., (2005). What drives mobile commerce? An empirical evaluation of the revised technology acceptance model. Information \& Management, Volume 42, Issue 5, July 2005, 719-729.

Kleijnen, M., Wetzels, M. and De Ruyter, K. (2004), “Consumer acceptance of wireless finance”, Journal of Financial Services Marketing, Vol. 8 No. 3, 206-217.

Newell, F., \& Newell-Lemon, K. (2001). Wireless rules. New York, NY: McGraw-Hill.

Kim C., Tao W., Shin N. and K.-S. Kim. (2010). An empirical study of customers' perceptions of security and trust in e-payment systems. Electronic Commerce Research and Applications, 9, 84-95.

Toh, T.W., Govindan, M., Chong, A.Y.-L., Keng-Boon, O. and Seetharam, A. (2009), "What drives Malaysian mcommerce adoption? An empirical analysis", Industrial Management + Data Systems, Vol. 109 No. 3, pp. 370-

Yogesh, J. (2013). Mobile Banking: A Study on Adoption \& Challenges in Southern Rajasthan, India. International Journal of Innovative Research \& Development. Volume 2. Issue 4., 902-914.

Hoehle, H. et al. (2012). Three decades of research on consumer adoption and utilization of electronic banking channels: A literature analysis. Decision Support Systems, Volume 54. Issue 1, December 2012, 122-132. 
Laukkanen, T., and Lauronen, J. (2005). Consumer value creation in mobile banking services. International journal of mobile Communications, 3(4), 325-338.

Venkatesh, V., and Davis. (2000). A Theoretical Extension of the Technology Acceptance Model: Four Longitudinal Field Studies. Management Science, 46(2): 186-204.

Koenig-Lewis, N. et al. (2010). Predicting young consumer's take up of mobile banking services. International Journal of Bank Marketing. Volume 28, Issue 5.

Roudaki, A. et al. (2015). A classification of web browsing on mobile devices. Journal of Visual Languages \& Computing, Volume 26, February 2015, 82-98.

Luarn, P. and Lin, H. (2005). Toward an understanding of the behavioural intention to use mobile banking. Computers in Human Behavior. Volume 21, Issue 6, November 2005, 873-891.

Dabholka, P.A. (1992). Role of affect and need for interaction in on-site service encounters, Advances in Consumer Research, Vol. 19 No. 1, 563-569.

Curran, J.M. and Meute, M.L. (2005). Self-service technology adoption: comparing three technologies, Journal of Services Marketing, Vol. 19 No. 2, 103-113.

Fragata, A. and Moustakas. E, (2013). Investigating the determinant's of E-Banking Loyalty for Large Business Customers: Two empirical models. Journal of Economics, Business and Management, Vol. 1, No. 2, May 2013, 204208.

Mick, D. and Fournier, S. (1998). Paradoxes of Technology Consumer Cognizance, Emotions, and Coping. Journal of Consumer Research, Vol. 25, 123-143.

Hanafizadeh, P. et al. (2014). A systematic review of Internet banking adoption. Telematics and Informatics 31, 492-510.

Lovelock, C.H. Wirtz, J. and Keh, H.T. (2002), Services Marketing in Asia: Managing People, Technology, and Strategy, Prentice Hall, Singapore.

Howcroft, B., Hamilton, R., and Hewer, P. (2002). Consumer attitude and the usage and adoption of home-based banking in the United Kingdom. International Journal of Bank Marketing, Vol. 20 No. 3, 111-2.

Patricio, L., Fisk, R. and Cunha, J. (2003). Improving Satisfaction with bank service offerings: measuring the contribution of each delivery channel. Managing Service Quality. Volume 3, Number 6, 471-482.

Mohammadi, H. (2015). A study of mobile banking loyalty in Iran. Computers in Human Behaviour, 44, 35-47. 